\title{
Faith, righteousness and salvation in Romans
}

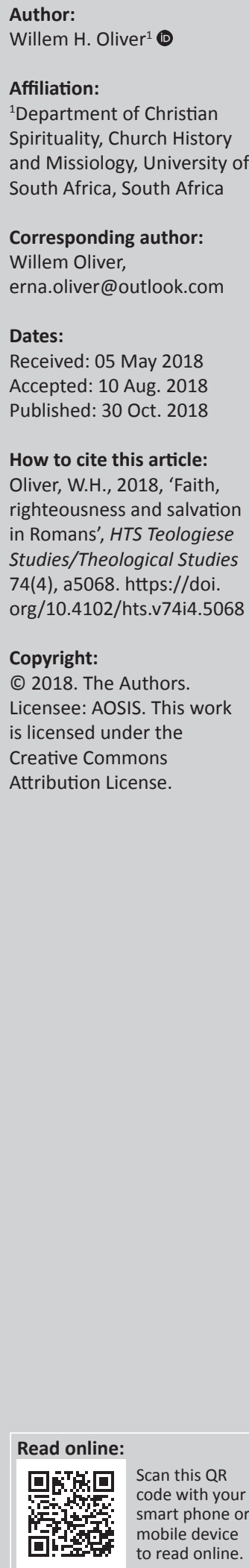

In the book of Romans, also called 'Paul's Letter/Epistle to the Romans', it is clear that Paul created a very close lexical semantic relation between the concepts $\pi$ í $\tau \imath \varsigma / \pi \imath \sigma \tau \varepsilon v \omega$ [faith,

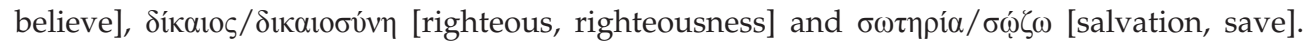
Although it is said that the theme of righteousness (by or through faith) is the focal point of Paul's theology, especially in Romans, this term is very closely linked to the two concepts, faith and salvation, in this letter. The aim of this article is to investigate that relation, specifically in the two passages of Romans 1:16-17 and 10:6a, 8b-10, in an attempt to come to an understanding of what Paul had in mind when he used these three terms together in these passages.

\section{Introduction}

The common difference in focus between the words of Jesus and the theology of Paul is said to be that Jesus has focused more on the kingdom of God (cf. Wilson 2014:2ff.), while Paul's arguments centred around righteousness ('justification') by or through faith (ex sola fide; cf. Van Aarde 2017:2 of 10; Heliso 2007:5-8; Stefon 2011:66, 281), especially in his letter to the Romans ${ }^{1}$ - this became a 'central Reformation doctrine' (cf. Dunn 1982:3 of 16). ${ }^{2}$ Some scholars refer to it as a central idea of Paul's theology (Seifrid 1992; cf. O'Brien 1992:69-95), while Bultmann (1971:217) argues that

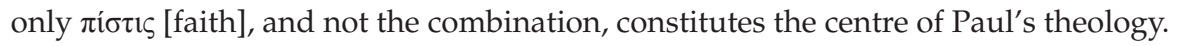

Two passages ${ }^{3}$ in this letter are highlighted and discussed, namely Romans 1:16-17 and 10:6a, $8 \mathrm{~b}-10 .{ }^{4}$ In these two passages the three terms - 'faith', 'salvation' and 'righteousness' - are related, and that relation is discussed. Romans 1:16-17 serves as Paul's Propositio (thesis, or basic contention) to his letter (Jewett 2006:135; cf. Garlington 2008:37), and therefore Romans 10 will be understood in light of the former.

\section{Introductory notes}

\section{Possible translations of the three terms and related terms}

From a grammatical point of view, Louw and Nida $(1988: 744 ; 452-453 ; 532 ; 570)$ refer to possible translations of $\pi i ́ \sigma \tau \iota \varsigma / \pi \imath \tau \varepsilon v ́ \omega, \delta ı \alpha \alpha \iota \sigma u ́ v \eta / \delta i ́ \kappa \alpha \iota \varsigma^{5}$ and $\sigma \omega \tau \eta \rho i ́ \alpha / \sigma \omega ́ \zeta \omega$, appearing or related to the two passages in discussion (interestingly, Rm 10:8-10 is not discussed in the entire lexicon); therefore only passages relevant to this discussion are quoted, together with possible translations:

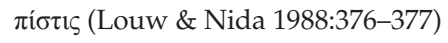

(b) to believe to the extent of complete reliance ( $\mathrm{Rm} 1: 17)$

$\pi \iota \tau \varepsilon v ́ \omega$ (Louw \& Nida 1988:378)

(c) to believe in the good news about Jesus Christ and to become a follower (Rm 1:16)

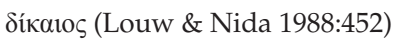

(b) be put right with (Rm 1:17)

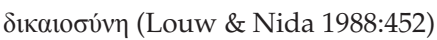

(b) to cause someone to be in a proper or right relation with someone else ( $\mathrm{Rm} 1: 17)$

1.Garlington (2008:37-38) rephrases these words with 'the availability of God's righteousness apart from the law', focusing more on the Old Testament.

2.Dunn (1982:3 of 16) refers to this interpretation as a 'Lutheran hermeneutic', which was followed by remarkable scholars such as Bultmann (1958:84) and Käsemann (1970:405). According to him, 'both read Paul through Lutheran spectacles and both made this understanding of justification by faith their central theological principle' (cf. also Vaino 2008).

3.Although only two passages are highlighted in this article, it is noted that Dunson (2011:23ff.) connects Romans 1:16-17 to both 3:21-5:2 and 9:30-10:17. The reason for this lies in his focus on ríotıs, while this article focuses on the three mentioned terms.

4.Oliver (2015:8 of 12) has already indicated that Romans 10:9-10 can be regarded as a hapax legomenon in the writings of Paul.

5.The term $\delta$ เкаı́ $\omega$ is not discussed here, as it does not appear in one of the two mentioned passages. 
According to the UBS3 (United Bible Societies) Dictionary

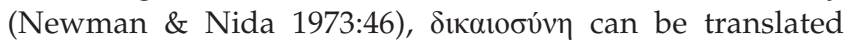
with 'righteousness', 'justice', 'justification' or '(God) putting (mankind) in a right relationship (with himself)'. From a theological point of view, a possible translation of

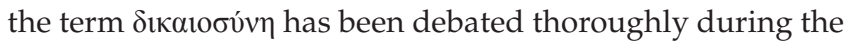
last half of the previous century. Dunn (1992:21) prefers 'justice', referring rather to the 'justice of God' than to the shift of Protestantism to 'justification by faith'. Bultmann (1951:271-272; 279-285) gives preference to 'righteousness of God' and sees it as a gift of God that he has bestowed on everyone who enters into the right relationship with him. This relationship is based on faith. Käsemann (1971:6-78)

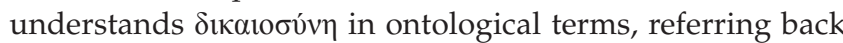
to the Jewish apocalyptic where the righteousness of God was connected to an obedience, producing power with reference to the individual. Wright (1991:148-151) regards

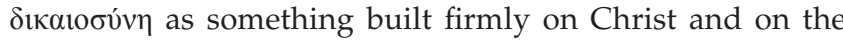
Holy Spirit, through Spirit-inspired faith in God, as it is revealed by Jesus Christ. Garlington $(2008: 23,24)$ refers to

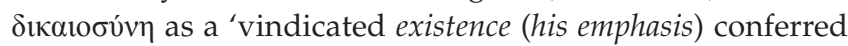
on a person by a gracious God', which is 'action-oriented' (in line with the Old Testament) and not merely 'status' or 'being' language.

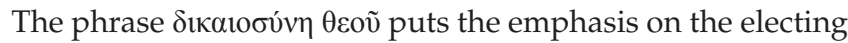
grace of God, as well as his covenantal mercy and his loving kindness (Garlington 2008:25). This phrase originates from the Old Testament 'in form and content' (Dunn 1982:10 of 16), especially the Psalms (cf. Ps 50:6; 51:14):

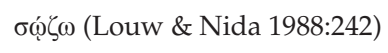

(b) to cause someone to experience divine salvation (Ac 13:25)

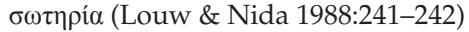

(b) salvation (state): a state of having been saved (2 Cor 7:10)

(c) salvation (event): the process of being saved (Ac 13:26)

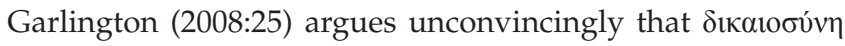
and $\sigma \omega \tau \eta \rho i ́ \alpha$ are 'synonymous'. The roots of his argument are found in the Old Testament, especially with reference to Isaiah 40-50, stating that 'God's righteousness is that aspect of his character which compels him to save Israel, despite the nation's perversity and lostness'. That there is a close link (called by Dunson 2011:25 an 'integral bond') between the two terms (in fact, actions) is obvious, but these terms are not interchangeable (contra Garlington). Later in his book, he states more convincingly that in Romans these two terms stand 'in parallel' to each other (Garlington 2008:43).

\section{Translation, ${ }^{6}$ structure and discussion}

For clarity's sake the two passages are given here with a possible (literary) translation and a structure (see Figure 1).

\section{Romans 1:16-17}

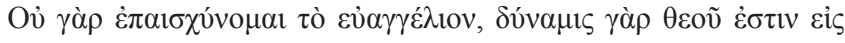

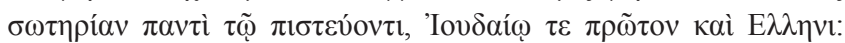
6.The translation of the NIV (2011) is mainly used, with alterations.

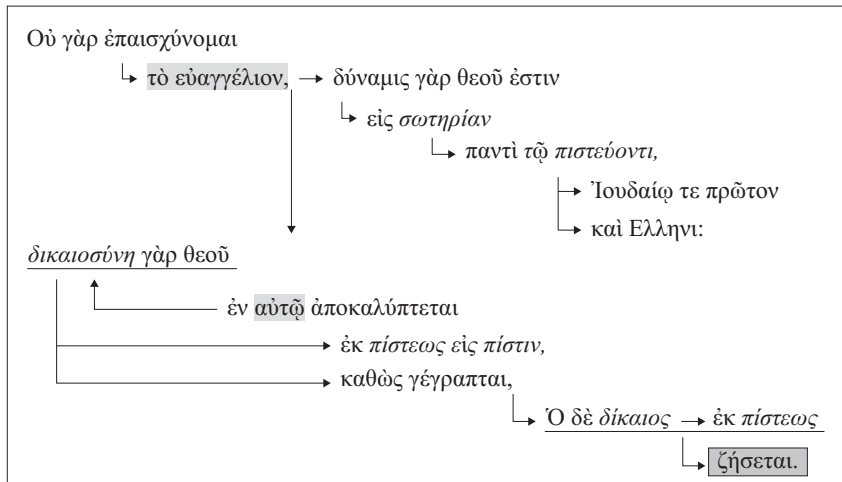

FIGURE 1: A structure of Romans 1:16-17.

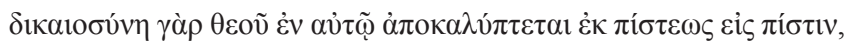

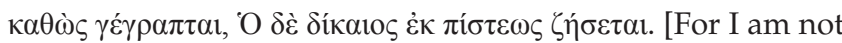
ashamed $^{7}$ of the gospel, because it is the power of God to the salvation of every believer, first to the Jew, then to the Gentile: For in it (the gospel) the righteousness of God is revealed from faith to faith, as it is written: 'The righteous person out/ because of faith will live].

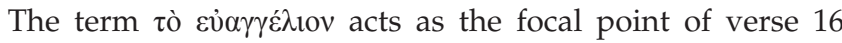
(linking to $\varepsilon \dot{b} \alpha \gamma \varepsilon \lambda i ́ \sigma \alpha \sigma \theta \alpha$ l of verse 15). Here Paul confesses

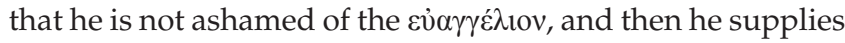

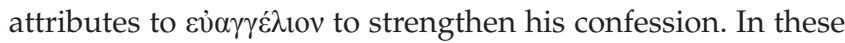

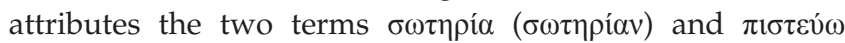
$(\pi \imath \sigma \tau \varepsilon v$ ov $\iota)$ are mentioned as part of these attributes. The link between verses 16 and 17 is found in the reference to

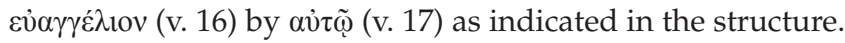

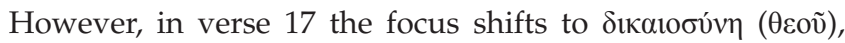
which is in fact another attribute of $\varepsilon \dot{v} \alpha \gamma \gamma \varepsilon \dot{\varepsilon} \lambda_{10 v}$, because the

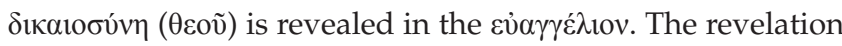

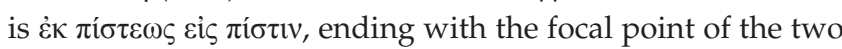

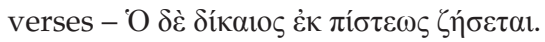

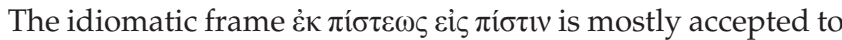
be translated with 'as exclusively a matter of faith' or 'of faith from beginning to end' (cf. Louw \& Nida 1988:692), emphatically setting forth an 'unbroken continuity' (Käsemann 1980:31). However, the translation of the sentence

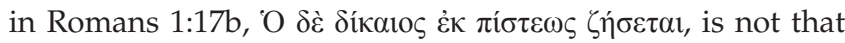
simple. This part of the verse is a quote from Habakkuk 2:4 and is also used in Galatians 3:11 and Hebrews 10:38. While most Bible translations like the NIV (2011), articles (cf. Bruce 1952:66-77; Smith 1967:13-25; Wallis 1973:17-23) and commentaries (cf. Bright \& Simons 2007; Haldane 1997:69; Hendriksen 1980:61; Kruse 2012:58) translate this sentence with ' $[t]$ he righteous will live by faith' (the 'traditional' translation), Louw and Nida (1988:377; cf. also Käsemann 1980:21) rightly propose, '[ $h]$ e who is righteous because of his faith shall live'. Only five English translations could be

7.This clause is in fact a confessional formula in which Paul actually says, "I confess the gospel' (cf. Stuhlmacher 1966:78) - discussed later in the article.

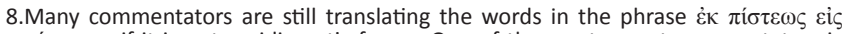

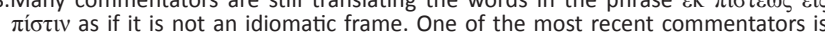
Kruse, who translates this phrase as follows: '... from the faith of the Jews first, and now growing also among the Gentiles' (Kruse 2012:78). Ziesler (1972:187) now growing also among the Gentiles' (Kruse 2012:78). Ziesler (1972:187) widened beyond a covenant with Israel and made universal'. 
found, translating the sentence in line with Louw and Nida (cf. Bible Study Tools 2017):

- Good News Translation (GNT): The person who is put right with God through faith shall live.

- Lexham English Bible (LEB): But the one who is righteous by faith will live.

- The Message Bible: The person in right standing before God by trusting him really lives.

- New Living Translation (NLT): It is through faith that a righteous person has life.

- Young's Literal Translation (YLT): And the righteous one by faith shall live.

Although the traditional translation is easier to comprehend, the second translation is more acceptable on a linguistical level. Macknight (1809:237; cf. also El Conquistador 2017) elaborates:

This translation is agreeable both to the order of the words in the original, and the apostle's design; which is to show that the doctrine of the gospel, concerning a righteousness by faith, is attested even by the prophets. Besides, it represents Habakkuk's meaning more truly than the common translation. For in the passage from which the quotation is made, Habakkuk describes the different dispositions of the Jews about the time they were threatened by the Chaldeans. Some of their souls were lifted up; they presumptuously trusted in their own wisdom and power, and, contrary to God's command, refused to submit to the Chaldeans, and were destroyed. But the just, or righteous, by faith, who believed God and obeyed his command, lived. However, as the reward of faith is not confined to the present life, persons who are just or good, by believing and obeying God, shall certainly live eternally. (p. 161)

Because Paul quoted directly from the Old Testament, he

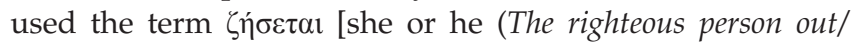
because of faith) will live], while it could well be that he

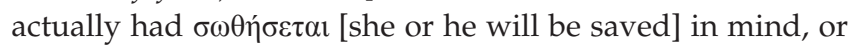
he regarded these two terms to be synonymous in this passage. This verse may link with Romans 5:18 where Paul referred to Jesus, who has put mankind right with God: кaì $\delta \imath^{\prime}$

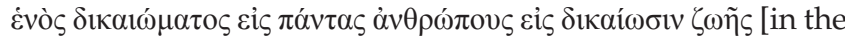
same way the one righteous act sets all people free and gives them life] (Louw \& Nida 1988:557, cf. 744), referring here to the act of salvation, giving the worshiper eternal life. There is therefore a very close link or even synonymity between the concepts 'being saved' and 'live eternally'.

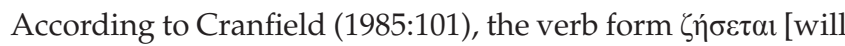
or shall live] refers to true life in God - 'the life which the believer is to begin to enjoy here and now, but which he [sic] will enjoy in its fullness in the eschatological future'. Meyer (1832), with reference to Habakkuk 2:4, agrees with Cranfield that the díkalos person will form part of the 'Messianic eternal life'. According to Kärkkäinen (2004:4-5) both salvation and justification point to unity with other Christians and also with God (see Figure 2).

\section{Romans 10:6a, 8b-10}

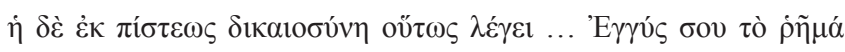

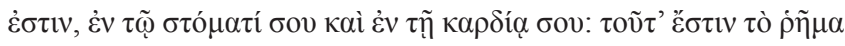

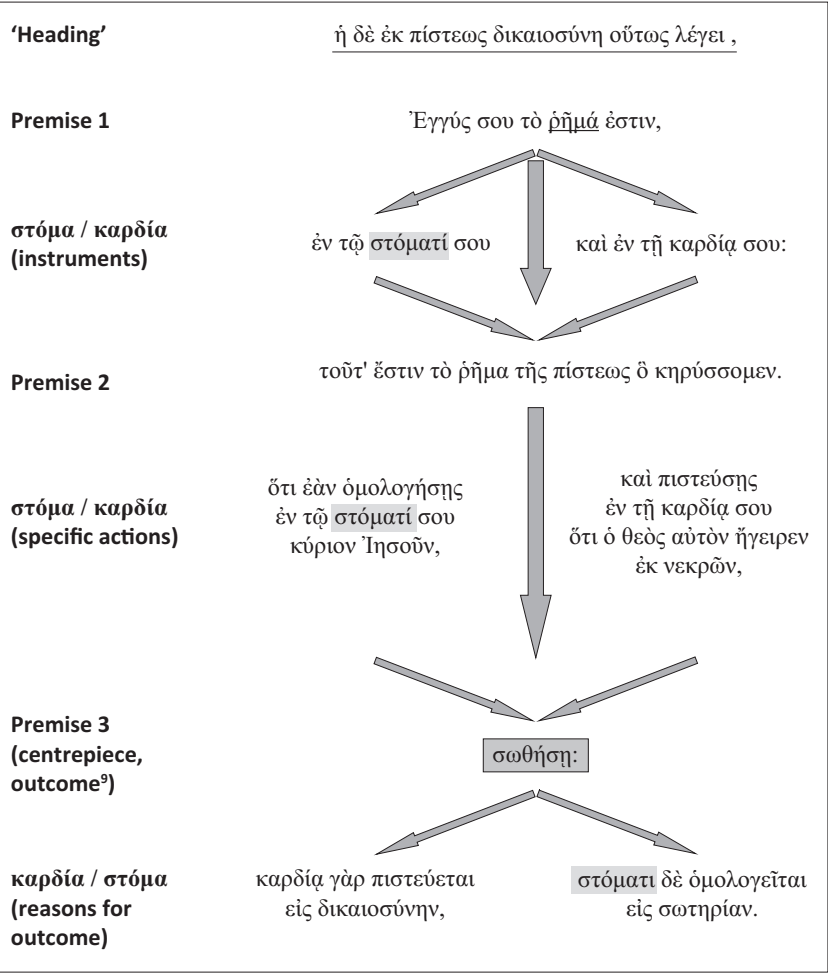

FIGURE 2: A structure of Romans 10:6a, 8b-10.

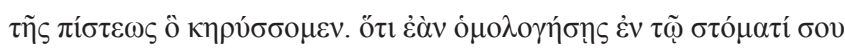

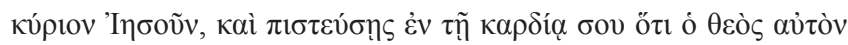

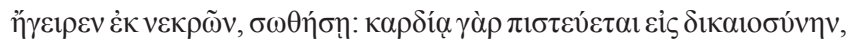

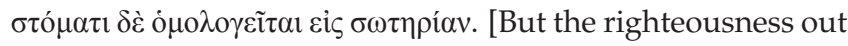
of faith means ${ }^{10} \ldots$ 'The word is close to you - in your mouth (on your lips) and in your heart: that is the word of faith that we proclaim'. For if you profess ${ }^{11}$ with your mouth Jesus as Lord, and you believe in your heart that God has raised him from the dead, you will be saved: For with the heart one believes to righteousness, and with the mouth one professes to salvation].

Romans 10:6a, 8b-10 immediately links with Romans 1:(16-)17

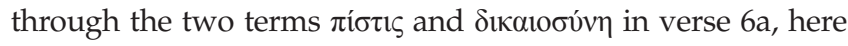
used as part of the 'heading' of this passage $e^{12}-\dot{\eta} \pi i ́ \sigma \tau \varepsilon \omega \varsigma$

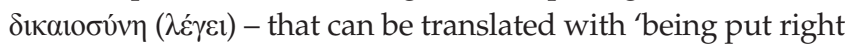
(actually, "the putting right") with God because of one's faith (means)'13 (cf. Newman \& Nida 1973:199). The heading together with the centrepiece or pinnacle of this passage ${ }^{14}$ (Premise 3: $\sigma \omega \theta \eta \dot{\sigma \eta})$ constitutes the focal point of this passage, in unison

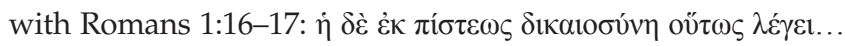
$\sigma \omega \theta \eta \dot{\sigma \eta \eta . ~}$

9.Cf. Newman and Nida (1973:201), who refer to it as "the result'. Käsemann (1980:291) calls it a 'pithy conclusion'.

10.According to Louw and Nida (1988:404) $\lambda \dot{\varepsilon} \gamma \omega$ (specifically $\lambda \varepsilon \dot{\gamma} \omega^{\mathrm{d}}$ ) can also be translated with 'mean'.

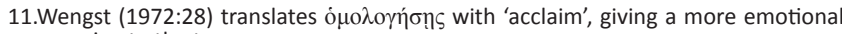
meaning to the term.

12.See Dunson (2011:33).

13. Interestingly, Käsemann (1980:290) still opts for the older version, 'righteousness because we believe'.

14.Jewett (2006:623) calls $\sigma \omega \theta \eta \dot{\sigma n}$ 'the central member of the entire chiasmus running through $10.6-10$ '. 
The heading is elaborated by three premises forming the backbone of the passage:

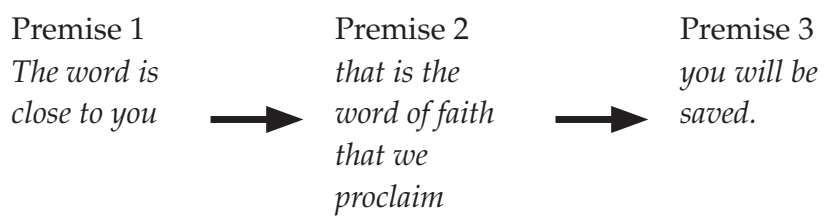

These premises form a crescendo in Premise 3, which acts as the centrepiece of the passage. In Premise 1 Paul refers to the $\dot{\rho} \tilde{\eta} \mu \alpha$ [i.e. the spoken message about faith], stating that it

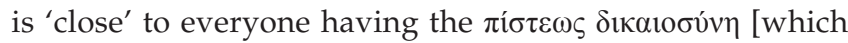
forms the thrust of the heading]. In Premise 2 he explicates the $\dot{\rho} \tilde{\mu} \mu \alpha$ by referring to it as the 'word of faith that we proclaim'. It is noteworthy that Paul duplicates the term

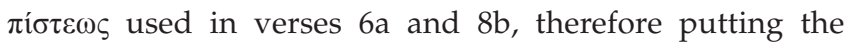
focus of what is to come on this term (as the action of the believer), although what follows is actually an elaboration

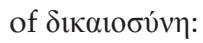

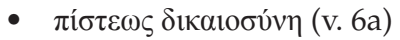

- $\tau$ ò $\rho \tilde{\eta} \mu \alpha \tau \tilde{\eta} \varsigma \pi i ́ \sigma \tau \varepsilon \omega \varsigma$ (v. 8b).

The third premise states clearly what the outcome of the proclaimed $\dot{\rho} \tilde{\eta} \mu \alpha$ for the believer would be: 'you will be saved'. Although it can be referred to as the content of the proclaimed $\dot{\rho} \tilde{\eta} \mu \alpha$ in this structure, it is stated to be the outcome in this passage, as it is preceded by two conditional clauses, supplying the outcome for it, and followed by the 'reasons' for this outcome, which can also be called the way in which the outcome is reached.

Verses $8 b-10$ consist of the content - the 'flesh' of or around

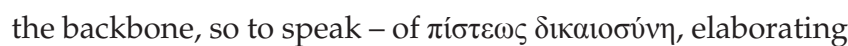
on what it means to be in the right relationship with God. Whereas Romans 1:16-17 mentions neither $\sigma \tau$ ó $\mu \alpha$ nor $\kappa \alpha \rho \delta i ́ \alpha$,

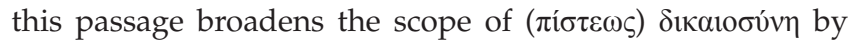
introducing these two terms after the first premise (here used in the dative singular, being referred to as the two instruments

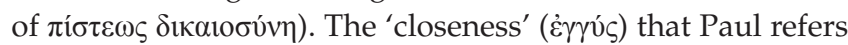
to in Premise 1 is actually an insideness to the believer: $\dot{\varepsilon} v \tau \tilde{\omega}$

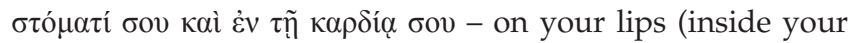
mouth) and inside your heart. After the second premise a specific action is allocated to each of these two instruments: What must be on one's lips, and what must live inside one's heart? This is a reference to the specific actions that these instruments should take. Here Paul uses conditional clauses to indicate what one should do with one's heart and mouth in

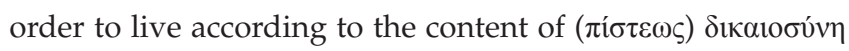
- in fact indicating that the believer has to execute these actions in order to receive the outcome. The insideness of the $\dot{\rho} \tilde{\eta} \mu \alpha$ creates a profession from inside the mouth of the believer that

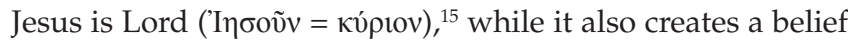
from inside the heart that God has risen him from the dead. Noteworthy is that both 'mouth' and 'heart' as the instruments

15.This profession or confession was the earliest form of creed (cf. Bright \& Simons 2007). are in fact the actual subjects of both verbs: the mouth professes and the heart believes.

On this point Paul makes the logical conclusion that God will save this believer. This third premise, being only one word in the form of a verb, $\sigma \omega \theta \eta \dot{\sigma n}$, depicts the outcome of the conditional clauses. If the instruments execute these actions,

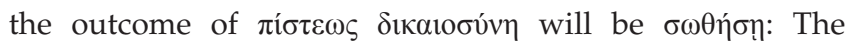
believer, professing Jesus as Lord and believing that God has raised her or him from the dead, will be saved by God. Following the third premise, Paul then gives the reasons for the outcome that he has just stated, therefore in which way the outcome is reached by the believer who has used her or his

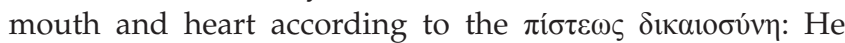
states unequivocally that the follower believes (with the

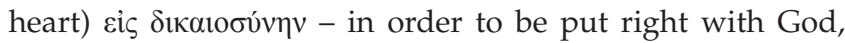
with the result that God puts her or him in the right relationship with him and that the believer professes (with

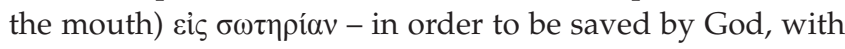
the result that God will save her or him. This part of the content actually duplicates the words of the conditional

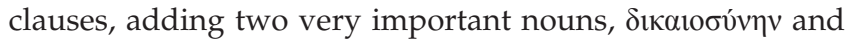
$\sigma \omega \tau \eta \rho i \alpha v$, which are in fact also duplications of nouns or verbs already being used in the passage (as will be discussed shortly).

The way in which Paul uses the two terms, $\sigma \tau$ ó $\mu \alpha$ and $\kappa \alpha \rho \delta i ́ \alpha$, in this context is set within the structure of a parallelismcum-chiasm. This means that there is much emphasis on these words and that they are therefore very important and relevant here. In light of the relation between faith, salvation and righteousness, as described above, and the premises that faith leads to righteousness ending up in salvation, Romans 10:9-10 pictures it as follows (cf. Ito 2006:250):

\begin{tabular}{|c|c|c|c|c|c|}
\hline ó & (a) & 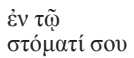 & (b) & & \\
\hline$\underline{\pi \imath \sigma \tau \varepsilon v ́ \sigma \prod \varsigma}$ & (c) & $\begin{array}{l}\dot{\varepsilon} v \tau \tilde{n} \kappa \alpha \rho \delta i ́ \alpha \\
\sigma o v\end{array}$ & (d) & & \\
\hline & $\underline{\sigma \omega \theta \eta \dot{\sigma n}}$ & (e) & & & \\
\hline 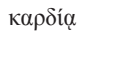 & (d) & 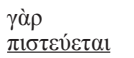 & (c) & 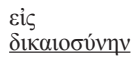 & (c1) \\
\hline$\sigma \tau o ́ \mu \alpha \tau \iota$ & (b) & $\begin{array}{l}\delta \dot{\varepsilon} \\
\dot{\alpha} \mu \mathrm{o} \lambda \mathrm{o} \gamma \varepsilon \tilde{\tau} \tau \alpha \mathrm{l}\end{array}$ & (a) & $\varepsilon i \zeta \varsigma \underline{\sigma \omega \tau \eta \rho i ́ \alpha v}$ & $(\mathrm{a} 1=\mathrm{e})$ \\
\hline
\end{tabular}

Figure 3 presents this intricate structure schematically.

This structure has a double parallelism, first linking Line 1 $(a-b)$ to Line $2(c-d)$, and then Line $3(d-c)$ to Line $4(b-a)$. It also contains a double chiasm (chiasmus), linking Line 1 (a-b) to Line 4 (b-a), followed by Line 2 (c-d) linked to Line 3 $(\mathrm{d}-\mathrm{c})$. Point $\mathrm{c}$ of Line 3 is extended to $\mathrm{c} 1$ (referring back to the heading of the structure), while Point a of Line 4 is extended to a1, which also equals e, which is the centrepiece of this structure - once again calling to mind the main terms in the focal point of this passage.

In this structure all the elements are clustered around the centrepiece $\sigma \omega \theta \eta \dot{\sigma \eta}$. The parallelism carries the mentioned 


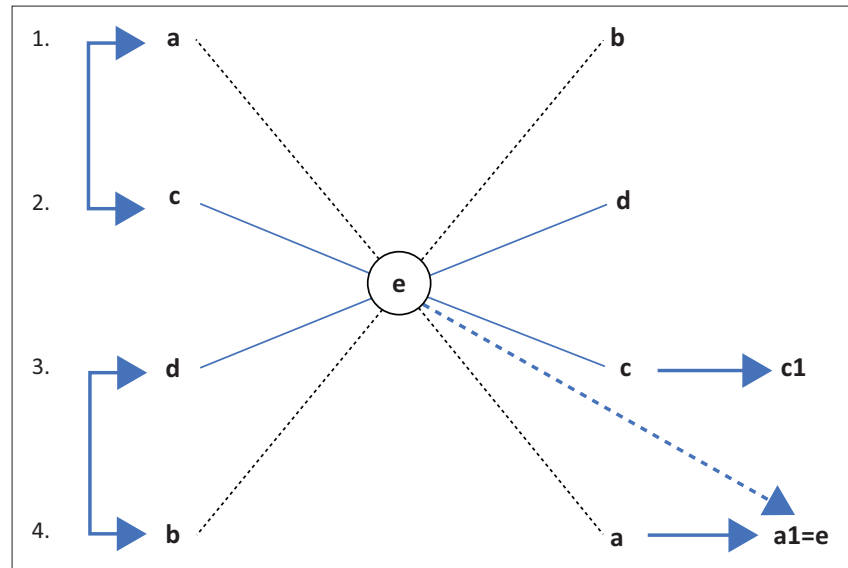

FIGURE 3: Schematic representation of Romans 10:9-10.

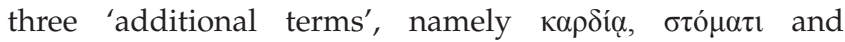

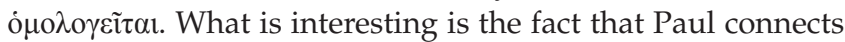

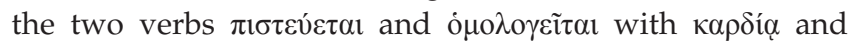
$\sigma \tau$ ó $\alpha \tau \imath$, respectively. Whereas 'faith' ('to believe') and 'righteousness' were 'singularly' connected to 'salvation', now 'faith' is first connected (attributed) to 'heart' before it results in 'righteousness', while the terms 'profess' and 'mouth' are added before ending up in 'salvation'. 'Heart' and 'mouth' are constituted as the sources of 'believe' and 'profess'.

\section{Parallellism:}

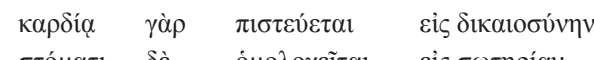

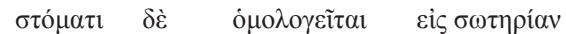

- with your heart you believe (have faith) and are justified (have righteousness)

- with your mouth you profess (your faith) and are saved (your salvation)

In the first part of the parallelism Paul uses both parts of the

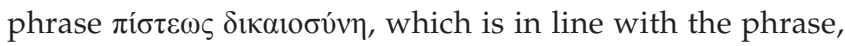

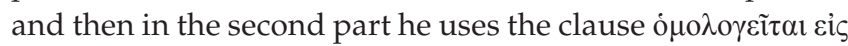
$\sigma \omega \tau \eta i^{\alpha} \alpha$. Verse 10a and 10b makes two identical statements,

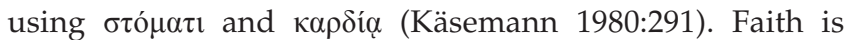
manifested in the profession or acclamation. These two clauses are not to be separated, each having its own meaning, as Paul is here referring to two sides of the same coin (cf. Newman \& Nida 1973:201). Ito (2006:250) concurs: 'They are the two aspects of the saving faith, two sides of one coin'.

While the three key terms of Romans 1:16-17, 'faith', 'righteousness' and 'salvation', are repeated here, the three 'new' terms that are added or introduced are 'profess', 'mouth' and 'heart'. With reference to the heading of this

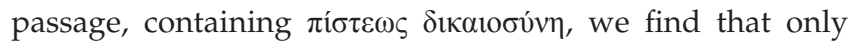
'believe' ('have faith') forms part of the first part of the chiasm $(\mathrm{a}-\mathrm{b}-\mathrm{c}-\mathrm{d})$, while 'righteousness' is introduced in the second part together with believe. Much in line with the discussion above, 'salvation/will be saved' forms the centrepiece of the structure $(\sigma \omega \theta \eta \dot{\sigma n})$ and also ends the structure with $\sigma \omega \tau \eta \rho i ́ \alpha$ :

$\begin{array}{llll}\begin{array}{l}\text { Passage } \\ \text { Romans }\end{array} & \begin{array}{l}\text { Righteous/ness } \\ \text { the righteous }\end{array} & \begin{array}{l}\text { Faith } \\ \text { out/because }\end{array} & \begin{array}{l}\text { Salvation } \\ \text { will live }\end{array} \\ \text { 1:16-17 } & \text { person } & \text { of faith } & \\ \text { Romans } & \text { the righteousness } & \text { out of faith } & \text { you will be } \\ \text { 10:6a, } 8 \mathrm{~b}-10 & & \text { means } & \text { saved }\end{array}$

\section{Conclusion}

Romans 1:16-17 and 10:6a, $8 b-10$ are two outstanding passages in this letter of Paul. In both these passages, in quite different ways, Paul reaches the same conclusion. The focal point of Romans 1:16-17 lies in the last statement in verse 17. The focus of Romans 10:6a, 8b-10 lies in the combination of the so-called heading and the centrepiece.

Both these passages therefore state unequivocally that when God puts someone in the right relation to him, that person will live - will be saved. Because righteousness comes from faith (out of faith), the order is actually as follows:

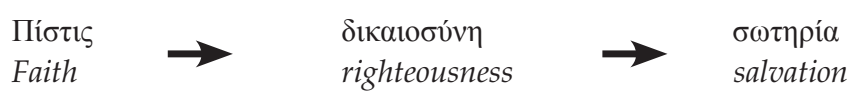

In the Propositio, specifically Romans 1:16, Paul refers to the gospel of God as his power, by which he saves every believer. In verse 17 Paul supplies the reason for this statement by relating that God's righteousness is revealed in the gospel. ${ }^{16}$ The revelation of God's righteousness is linked to the enduring faith of the believers, which means: God will save the person who has this righteousness in her or him (the one whom God has put in a right relationship with himself because of her or his faith) - that person will live (eternally - Macknight 1809), implying that God will save that person. ${ }^{17}$ The link between faith, righteousness and salvation is therefore very strong in these two verses - from the view of the gospel.

In Romans 10:6a Paul again links righteousness to faith by stating that righteousness for mankind has faith as its source (righteousness out of faith). However, where Paul has referred

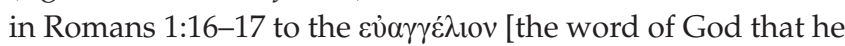
has given to people, therefore the word of God received by people], in Romans 10:8b he refers to the $\dot{\rho} \tilde{\mu} \mu \alpha^{\text {[the word of }}$ God spoken or professed by people]. Where Paul has

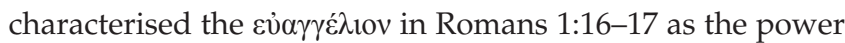
of God, because his righteousness shines through the gospel and is revealed in constant faith, the spoken word of Romans 10 is located in(side) the believer - in the mouth and the heart. Paul then explicates what he means by using these two

16.Käsemann (1980:22) makes a strong case for the fact that gospel 'is more than the message actualized in the church. It is God's declaration of salvation to the world ...

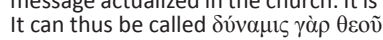

17.This seems to be in stark contradiction to Romans 2:6, where Pauls states clearly: ôs

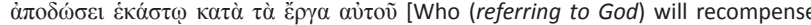
everybody according to what they have done]. According to Newman and Nida (1973:35), Paul pictures no contradiction here with what he has stated in Romans 1 and in the rest of his letter. 'What they have done' refers to obedience to the law. and in the rest of his letter. 'What they have done' refers to obedience to the law. Dunn (1982:3 of 16) confirmed this premise satisfactorily, stating that for the 1st-century Judaism everything was an elaboration of the fundamental axiom that the one God had chosen Israel to be his peculiar people, to enjoy a specia relationship under his rule. The law had been given as an expression of this covenant, to regulate and maintain the relationship established by the covenant. So too, righteousness must be seen in terms of this relationship, as referring to conduct appropriate to this relationship, conduct in accord with the law [emphasis added]'. 
'instruments': Because the focus in this passage is on the spoken word, it relates to the heart and the mouth (lips) of the believer. By using the extended parallelism-cum-chiasm structure in Romans 10:9-10, he puts emphasis on the fact that salvation is borne out of profession and faith. The chiasm

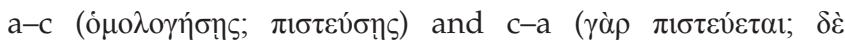

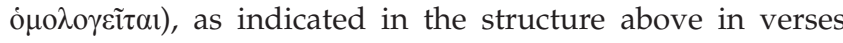
9-10, is, according to Käsemann (1980:291), 'the summary of faith for the believer'.

According to Garlington (2008:38; cf. also Dunson 2011:28), Romans 10:10 connects to Romans 1:16, where both concentrate on the will to confess (cf. Stuhlmacher 1966:78 in fn. 8), over against a refusal to confess, referred to by Paul as 'shame' (Rm 1:16). Garlington (2008) elaborates on his statement:

Judaism was a confessing religion, and to confess oneself to be Jewish was to commit oneself to the ideal of Israel as a social, political and religious ethnos (his emphasis); and it is precisely this which calls forth Paul's declaration that he is not ashamed of the gospel, i.e., he confesses it. (p. 39)

Faith-righteousness-salvation is the focal point for every Christian believer - whether it was during the days that the Bible was written (or even before that, when the people only had Yahweh to believe in) or today, where Christians all over the world are so divided because of dogma. Maybe every believer should go back to the book of Romans and read it as it was written - with a passion for Christ. This will make us look past our small dogmatic differences and bring us to the confession: For I am not ashamed of the gospel (I therefore profess the gospel), because it is the power of God to the salvation of every believer.

\section{Acknowledgements Competing interests}

The author declares that he has no financial or personal relationships which may have inappropriately influenced him in writing this article.

\section{References}

Bible Study Tools, 2017, Compare translations for Romans 1:17, viewed 08 Decembe 2017, from https://www.biblestudytools.com/romans/1-17-compare.html

Bright, H. \& Simons, K., 2007, Paul's letter to the Romans: An EasyEnglish Bible version and commentary (2800 word vocabulary) on the Book of Romans, viewed 05 December 2017 from https://www.easyenglish.bible/bible-commentary/romanslbw.htm

Bruce, F.F., 1952, 'Justification by faith in the non-Pauline writings of the New Testament', The Evangelical Quarterly 24(2), 66-77.

Bultmann, R.K., 1951, Theology of the New Testament, vol. 1, transl. K. Grobel, Scribners, New York.

Bultmann, R.K., 1958, Jesus Christ and mythology, Scribner, London.

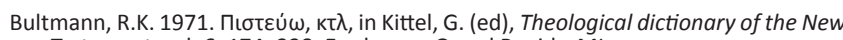
Testament, vol. 6, 174-228, Eerdmans, Grand Rapids, MI.

Cranfield, C.E.B., 1985, A critical and exegetical commentary on the Epistle to the Romans, Vol.1 Romans 1-8, (The International Critical Commentary), T. \& T. Clark, Edinburgh.
Dunn, J.D.G., 1982, The new perspective of Paul, The Manson Memorial Lecture delivered in the University of Manchester on 4 November 1982, viewed
19 April 2018, from https://www.rts.edu/Site/Academics/Docs/Syllabi/Washington/ 19 April 2018, from https://www.rts.edu/Site/Academics/Docs/S
2007/2007-02-NT518-Dunn_New_Perspective_on_Paul.pdf

Dunn, J.D.G., 1992, 'The justice of God: A renewed perspective on justification by faith', Journal of Theological Studies NS 43, 1-22. https://doi.org/10.1093/jts/43.1.1

Dunson, B.C., 2011, 'Faith in Romans: The salvation of the individual or life in community?', Journal for the Study of the New Testament 34/1, 19-46. https:// doi.org/10.1177/0142064X11415328

El Conquistador, 2017, James MacKnight, 1795: Romans 1:1-17, viewed 10 December 2017, from http://elconquistador.org/mcknight-romans-chapter-1/

Garlington, D. (ed.), 2008, Studies in the new perspective on Paul: Essays and reviews, Wipf and Stock Publishers, Eugene, OR.

Haldane, R., 1997, Exposition of the Epistle to the Romans (The Ages Digital Library Commentary), Ages Software, Albany, OR.

Heliso, D., 2007, Pistis and the righteous one: A study of Romans 1:17 against the background of scripture and the Second Temple Jewish literature, Mohr Siebeck, Tübingen.

Hendriksen, W., 1980, Romans, Vol. 1 Chapters 1-8 (New Testament Commentary), The Banner of Truth Trust, Edinburgh.

Ito, A., 2006, 'The written Torah and the oral Gospel: Romans 10:5-13 in the dynamic tension between orality and literacy', Novum Testamentum 48/3, 234-260. https://doi.org/10.1163/156853606777836381

Jewett, R., 2006, Romans: A commentary (Hermeneia Series), Fortress Press, Minneapolis, MN.

Kärkkäinen, V.-M., 2004, One with God: Salvation as deification and justification, Liturgical Press, Collegeville, Minnesota, MN.

Käsemann, E., 1970, Das Neue Testament als Kanon, Vandenhoeck \& Ruprecht, Gottingen.

Käsemann, E., 1971, Perspectives on Paul, transl. M. Kohl, SCM Press, London.

Käsemann, E., 1980, Commentary on Romans, Wm. B. Eerdmans Publishing Co., Grand Rapids, MI.

Kruse, C.G., 2012, Paul's letter to the Romans, The Pillar New Testament Commentary, Wm. B. Eerdmans Publishing Co., Grand Rapids, MI

Louw, J.P. \& Nida, E.A., 1988, Greek-English Lexicon, vol. 1, United Bible Societies, New York.

MacKnight, J., 1809, A new literal translation from the original Greek, of all the Apostolic Epistles, with a commentary, and notes, philological, critical, explanatory, and practical, vol. 1, 4th edn., Longman, Hurst, Rees, and Orme, Paternoster-Row, London.

Meyer, H.A.W., 1832, Meyer's critical and exegetical commentary on the New Testament, viewed 08 December 2017, from https://www.studylight.org/ commentaries/hmc/romans-1.html

Newman, B.M. \& Nida, E.A., 1973, 'Helps for translators', in A translator's handbook on Paul's letter to the Romans, vol. 14, United Bible Societies, Stuttgart.

NIV (New International Version), 2011, Holy Bible, viewed 07 December 2017, from https://www.biblegateway.com/passage/?search=rm+1\&version=NIV

O'Brien, P.T., 1992, 'Justification in Paul and some crucial issues of the last two decades', in D.A. Carson (ed.), Right with God: Justification in the Bible and the world, pp. 69-95, Baker and Carlisle, Grand Rapids, MI.

Oliver, W.H., 2015, 'Romans 10:5-13 revisited', HTS Theological Studies 71(3), Art. \#2929, 12 pages. https://doi.org/10.4102/hts.v71i3.2929

Seifrid, M.A., 1992, Justification by faith: The origin and development of a central Pauline theme, Brill, Leiden.

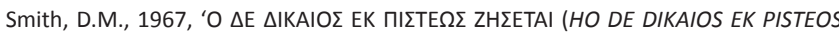
ZESETAI', in B.L. Daniels \& M.J. Suggs (eds.), Studies in the history and text of the New Testament in honor of Kenneth Willis, pp. 13-25, University of Utah Press, Salt Lake City, UT. Studies and Documents 29.

Stefon, M., 2011, Christianity: History, belief, and practice, Britannica Educational Publishing, New York.

Stuhlmacher, P., 1966, Gottes Gerechtigkeit bei Paulus (FRLANT 87) Vandenhoeck \& Ruprecht, Göttingen.

Vaino, O.-P., 2008, Justification and participation in Christ: The development of the Lutheran doctrine of justification to the Formula of Concord (1580), Brill, Leiden.

Van Aarde, A.G., 2017, "'By faith alone" (undivided loyalty) in light of change agency theory: Jesus, Paul and the Jesus-group in Colossae', HTS Theological Studies 73(3), a4355. https://doi.org/10.4102/hts.v73i3.4355.

Wallis, W.B., 1973, 'The translation of Romans 1:17: A basic motif in Paulinism' Journal of the Evangelical Theological Society 16(1), 17-23.

Wengst, K., 1972, Christologische Formeln und Lieder des Urchristentums, Gütersloher Verlagshaus Gerd Mohn, Gütersloh.

Wilson, B., 2014, Paul vs. Jesus, York University, Toronto, viewed 07 December 2017, from http://www.barriewilson.com/pdf/Paul-vs-Jesus.pdf

Wright, N.T., 1991, The climax of the covenant, T. \& T. Clark, Edinburgh.

Ziesler, J.A., 1972, The meaning of righteousness in Paul: A linguistic and theological enquiry (SNTSMS 20), Cambridge University Press, Cambridge. 